\title{
Accumulated heat unit and phenology of diverse maize varieties as affected by planting dates under Rampur condition, Nepal
}

LP Amgain*

\begin{abstract}
Accumulated heat unit and phenology of a full season open pollinated and three specialty corn (Zea mays L.) cultivars (Hybrid, QPM and Pop) were studied by growing them on three different planting dates (September 1, October 1 and November 1) in RCB design at Rampur Chitwan, Nepal during the winter season of 2009-10. The results indicated that the number of days required to attain different phenological stages were short for the early winter and gradually long for late winter plantings. For all the phenological studies, plants of normal sowing condition (September 1) recorded comparatively higher heat units than the late planting (October 1 and November 1) for all cultivars. Both early and late plantings recorded the higher helio-thermal units at advanced growth phases than at the early stages. The pheno-thermal indices at the earlier growth stages were significantly higher for early planting than the late plantings. The heat use efficiency (HUE) was found to be higher under normal planting as compared to the late plantings. Popular maize variety Rampur Composite was found to be the most suitable to produce stable HUE than the other varieties tested. The specialty corn cultivars could not show stable yield in late planting conditions suggesting their planting could be better for September sowing during early winter seasons.
\end{abstract}

Key words: Diverse maize varieties, planting dates, phenology, GDD, heat use efficiency

\section{Introduction}

The growth phases of any variety of crops are determined basically with growing season in which the atmospheric ambient temperature and solar radiation are the major governing factors. Several researchers have shown the influence of temperature on phenology and yield of crops and expressed it under field conditions through accumulated heat unit system (Sikdar, 2009, Rao et al, 1999, Bishnoi et al., 1995, Rao and Singh, 2007). Plants have a definite temperature requirement before they attain certain phenological stages and to forecast the phenology and crop production attributes for a large acreage, there has been the development of crop models (Dooraiswamy and Thompsosn, 1982, Jones et al, 2003). The heat unit system was adopted for determining the maturity dates of different crops (Bierhuizen, 1973) from which accurate yield and maturity prediction could be assessed.

\footnotetext{
*IAAS Rampur Campus, Rampur, Chitwan, Nepal. amgainlp@gmail.com
} 
Though maize is a day neutral plant, the flowering and maturity of its varieties are however, dependent to available temperature and sunshine hours and it is location specific (Rao et al., 1999, Bonhaomme et al., 1994). Hence, the knowledge on the calculation of the heat summation unit (HSU), mostly called the growing degree days (GDD) and their further mathematical derivations like helio-thermal unit (HTU), pheno-thermal index (PTI) and heat use efficiencies (HUE) will be the basic principles to understand the phenology and follow the proper planting times for different crop varieties over the spatial and temporal variations (Sreenivas et al., 2010, Rajput, 1980).

Winter maize (August-January) being of versatile uses and high yielding is substituting wheat, mustard and several other winter crops in central Terai of Nepal (Gurung, 2010). It has been experienced that the late planting of winter maize after second fortnight of October is suffered with adverse fall in temperature at the early growth stages (NMRP, 2008). The lower temperature below the base temperature $\left(8^{0} \mathrm{C}\right)$ during the winter sometimes adversely affects the maize yield and late winter planting is considered less monetary returning than the early spring planting (Amgain, 2011). In this regard, planting date will have determinant role in governing the maize growth and yields. The phenology and ambient temperature interaction studies in winter maize is very rare except few in spring and winter maize both at Rampur, Chitwan, Nepal (Amgain, 2011). In present investigation, the effect of ambient temperature on phenological development and accumulated heat unit of the diverse varieties of maize was studied to determine the real heat unit indices grown under different planting dates.

\section{Materials and methods}

The phenological (emergence, knee high, tasseling, anthesis, grain filling and physiological maturity) and yield data for this study had been taken from field experiment at the Agronomy Department of Rampur Campus. Four diverse maize cultivars: Open pollinated maize (Rampur Composite), Quality Protein Maize (Posilo Makai-1), Hybrid (Gaurav) and Pop corn (Pool-12) were grown on three seeding dates: September 1, October 1 and November 1 in 2009. The experiment was conducted in Randomized Complete Block Design (RCBD) having three replications and standard package of practices was followed to grow the maize (Reddy, 2009). Ten fixed maize plants from each plot were randomly selected from emergence and fixed up to the physiological maturity stages to visualize their different pheno-phases and 75\% developmental stages have been marked for this study. The daily weather data records were collected from the Meteorological Observatory of National Maize Research Program, Rampur, Chitwan and the average mean temperature attained by the various maize cultivars from sowing to physiological maturity has been depicted in Fig 1. Similarly, the mean sunshine hours from one developmental stage to the other stage for a particular planting date and variety was also taken including with the average temperature for the further mathematical expressions. The various measurements of accumulated heat 
units were calculated according to the following formulae given by Rao et al. (2000), Singh et al. (1998) Ritchie and Nesmik (1991 and Rajput (1980).

1. Growing degree days $(\mathrm{GDD})=\{(\mathrm{T} \max +\mathrm{T} \min ) \div 2\}-\mathrm{Tb}$

$\left(\mathrm{T} b=\right.$ Base temperature $\left.=10{ }^{\circ} \mathrm{C}\right)$

2. Helio-thermal unit $(\mathrm{HTU})=\mathrm{GDD} \times$ Duration of sunshine hours

3. Pheno-thermal index $(\mathrm{PTI})=\mathrm{GDD} \div$ Growth days

4. Heat use efficiency $(\mathrm{HUI})=$ Grain yield $(\mathrm{kg} / \mathrm{ha}) \div$ GDD

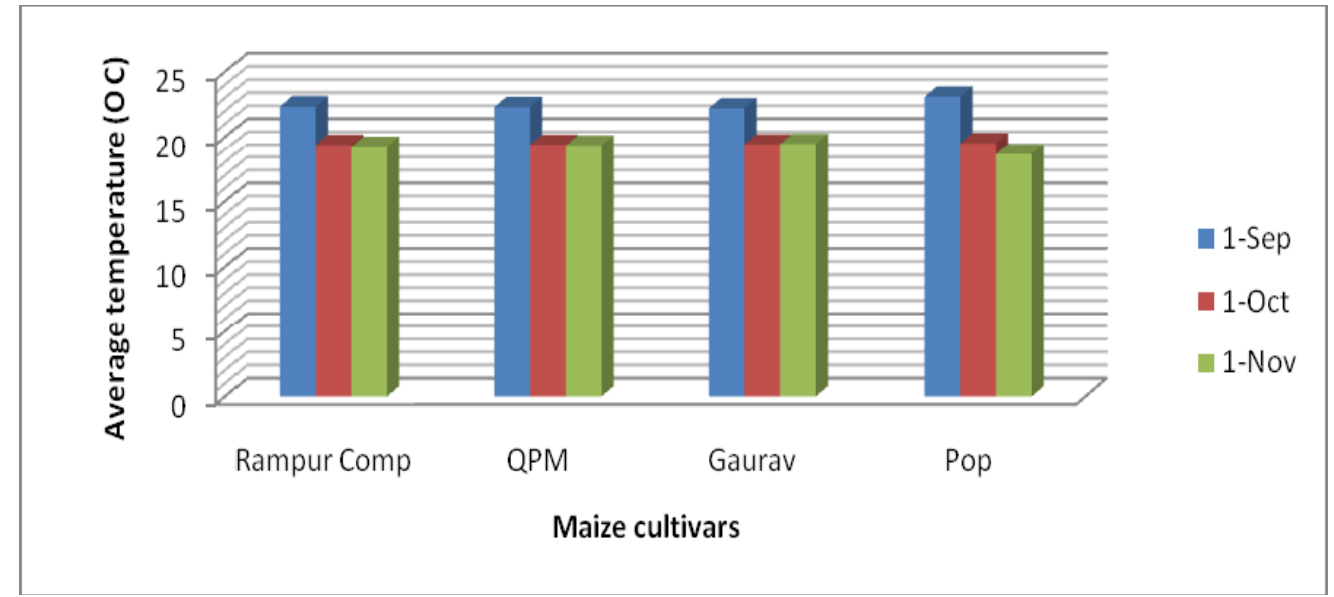

Figure 1. Average mean temperature received by different maize cultivars in winter 2009/10

\section{Results and discussions}

\section{Phenology}

The phenology results showed that days for attainment of different phenological stages differed significantly from cultivar to cultivar and planting dates (Table 1). Under normal growing condition, Gaurav required the highest days to attain to emergence, knee high $(\mathrm{KH})$, tasseling, anthesis, grain filling and maturity followed by QPM, Rampur-Composite and Pop corn. Pop corn required the significantly lowest number of days for attaining different phenological stages. Under the 1st September planting, Rampur Composite required 5 days for emergence, 35 days for $\mathrm{KH}, 48$ days for tasseling, 63 days for anthesis, 100 days for grain filling and 135 days for maturity, whereas for Pool-12, the mentioned growth duration were 4, 33, 45, 60, 92 and 123 days, respectively. At late growing conditions (1st November planting) more lengthy days were attained to get the respective pheno-phases and maturity than the 1st September planting to all the cultivars because of decreased temperatures for attaining different phenological growth stages. High temperature at the early vegetative phases of maize was resulting in reduced number of days for attaining different phenological stages under normal planting. This work is in accordance with Amgain (2011), Ghosh et al. (2000), Paul and Sarker (2000), Sandhu et al. (1999). 
Table 1. Phenology (days after sowing) of different maize cultivars as affected by planting time

\begin{tabular}{|c|c|c|c|c|c|c|}
\hline \multirow[b]{2}{*}{ Treatment } & \multicolumn{6}{|c|}{ Growth stages of maize } \\
\hline & Emergence & Knee high & Tasseling & Anthesis & $\begin{array}{l}\text { Grain } \\
\text { filling }\end{array}$ & $\begin{array}{c}\text { Physiological } \\
\text { maturity }\end{array}$ \\
\hline \multicolumn{7}{|c|}{ Rampur Composite } \\
\hline Sept 1 & 5 & 35 & 48 & 63 & 100 & 135 \\
\hline Oct 1 & 6 & 45 & 63 & 78 & 17 & 144 \\
\hline Nov 1 & 10 & 67 & 85 & 103 & 125 & 151 \\
\hline \multicolumn{7}{|c|}{ QPM (Posilo Makai-1) } \\
\hline Sept 1 & 5 & 36 & 51 & 66 & 102 & 136 \\
\hline Oct 1 & 7 & 47 & 67 & 83 & 115 & 148 \\
\hline Nov 1 & 12 & 68 & 88 & 105 & 129 & 153 \\
\hline \multicolumn{7}{|c|}{ Hybrid (Gaurav) } \\
\hline Sept 1 & 5 & 37 & 54 & 68 & 105 & 138 \\
\hline Oct 1 & 7 & 48 & 70 & 85 & 118 & 150 \\
\hline Nov 1 & 13 & 69 & 92 & 107 & 130 & 155 \\
\hline \multicolumn{7}{|c|}{ Pop corn (Pool-12) } \\
\hline Sept 1 & 4 & 33 & 45 & 60 & 92 & 123 \\
\hline Oct 1 & 5 & 43 & 59 & 74 & 103 & 133 \\
\hline Nov 1 & 9 & 60 & 80 & 100 & 122 & 140 \\
\hline $\operatorname{LSD}(0.05)$ & 1.5 & 4.78 & 6.44 & 9.12 & 7.81 & 3.33 \\
\hline
\end{tabular}

\section{Growing degree days (GDD)}

Combined effect of growing conditions and cultivars on heat unit of GDD for all the phenological stages has been presented in Table 2. For all the cultivars and planting time, the later developmental stages (tasseling, anthesis, grain filling and maturity) showed the increasing trend of heat unit (GDD) than at the emergence and knee high. The significantly highest GDD requirement was observed in Gaurav hybrid at maturity stage (1495 degree days), whereas the lowest values of GDD for Pop-12 (1217 deg days) on $1^{\text {st }}$ November planting. The requirement of heat unit GDD was significantly higher for normal planting condition than the late condition. Late planting increased the duration of phenology as compared to normal planting due to fluctuated unfavorable temperature for different phenological stages with late planting. Sandhu et al. (1999) and Paul and Sarker (2000) also reported that requirement of heat units decreased for different phenological stages with delay in sowing of wheat. 
Table 2. Growing degree days (GDD) at different phonological stages of different maize cultivars as affected by planting time

\begin{tabular}{|c|c|c|c|c|c|c|}
\hline \multirow[b]{2}{*}{ Treatment } & \multicolumn{6}{|c|}{ Growth stages of maize } \\
\hline & Emergence & Knee height & Tasseling & Anthesis & $\begin{array}{l}\text { Grain } \\
\text { filling }\end{array}$ & $\begin{array}{c}\text { Physiological } \\
\text { maturity }\end{array}$ \\
\hline \multicolumn{7}{|c|}{ Rampur Composite } \\
\hline Sept 1 & 114.85 & 686.65 & 900.45 & 1107.25 & 1467.35 & 1677.65 \\
\hline Oct 1 & 126.6 & 664.2 & 833.3 & 949.3 & 1110.95 & 1361.05 \\
\hline Nov 1 & 127.7 & 573.65 & 667.25 & 793.95 & 1010.6 & 1404.5 \\
\hline \multicolumn{7}{|c|}{ QPM (Posilo Makai-1) } \\
\hline Sept 1 & 114.85 & 705.15 & 944.05 & 1043.1 & 1180.4 & 1684.05 \\
\hline Oct 1 & 142 & 688.3 & 866.95 & 980.95 & 1148.63 & 1339.35 \\
\hline Nov 1 & 150.65 & 579.65 & 687.8 & 809.7 & 1060.05 & 1438.5 \\
\hline \multicolumn{7}{|c|}{ Hybrid (Gaurav) } \\
\hline Sept 1 & 104.85 & 720.55 & 985.1 & 1166.05 & 1502.45 & 1694.95 \\
\hline Oct 1 & 142 & 700.3 & 888.8 & 996.4 & 1169.65 & 1423 \\
\hline Nov 1 & 164.85 & 585.85 & 718.1 & 824.8 & 1172.3 & 1473.75 \\
\hline \multicolumn{7}{|c|}{ Pop corn (Pool-12) } \\
\hline Sept 1 & 98.2 & 652.55 & 851.9 & 1067.4 & 1463.1 & 1622 \\
\hline Oct 1 & 110.1 & 639.5 & 799.3 & 915.9 & 1089.3 & 1273.15 \\
\hline Nov 1 & 116.45 & 545.6 & 641.25 & 769.1 & 975.45 & 1217.35 \\
\hline $\operatorname{LSD}(0.05)$ & 15.6 & 47.8 & 65.4 & 92.62 & 77.33 & 32.85 \\
\hline
\end{tabular}

\section{Helio-thermal units}

Helio-thermal unit of a definite phenology is the product of the length of sunshine hours of a day and accumulated heat units of those particular pheno-phases shown by plants. The requirements of HTU for normal planting conditions were significantly higher than the late planting conditions with few exceptions with some cultivars and planting dates (Table 3). The variation of sunshine hours recorded at different developmental stages of maize has affected the magnitudes of the HTU though there were records of higher GDD at advanced stages of the maize. The random trend of HTU for different phenological stages was also found to be for late sown wheat (Rajput et al., 1987; Paul and Sarker, 2000 and Hauqe et al., 2000). 
Table 3. Helio-thermal unit (HTU) at different phonological stages of different maize cultivars as affected by planting time

\begin{tabular}{|c|c|c|c|c|c|c|}
\hline \multirow[b]{2}{*}{ Treatments } & \multicolumn{6}{|c|}{ Growth stages of maize } \\
\hline & Emergence & $\begin{array}{c}\text { Knee } \\
\text { height }\end{array}$ & Tasseling & Anthesis & $\begin{array}{l}\text { Grain } \\
\text { filling }\end{array}$ & $\begin{array}{c}\text { Physiological } \\
\text { maturity }\end{array}$ \\
\hline \multicolumn{7}{|c|}{ Rampur Composite } \\
\hline Sept 1 & 499.4 & 4648.4 & 5312.7 & 7307.9 & 7626.7 & 7953.0 \\
\hline Oct 1 & 711.5 & 4762.3 & 4699.8 & 6198.9 & 7455.1 & 8288.8 \\
\hline Nov 1 & 969.3 & 2935.9 & 3344.4 & 4827.4 & 7953.4 & 10028.1 \\
\hline \multicolumn{7}{|c|}{ QPM (Posilo Makai-1) } \\
\hline Sept 1 & 490.4 & 3962.9 & 6561.1 & 7792 & 7625.4 & 8294.3 \\
\hline Oct 1 & 1181.4 & 4365.2 & 5093.4 & 5854.9 & 6962.1 & 9027.2 \\
\hline Nov 1 & 1116.3 & 2793.9 & 3492.5 & 4129.5 & 5261.4 & 12371.1 \\
\hline \multicolumn{7}{|c|}{ Hybrid (Gaurav) } \\
\hline Sept 1 & 490.4 & 8995 & 7605 & 6932.3 & 8780.4 & 9856.1 \\
\hline Oct 1 & 1181.4 & 5056.2 & 4817.3 & 5878.8 & 6140.7 & 11341.3 \\
\hline Nov 1 & 1210 & 3175.3 & 4437.9 & 5229.2 & 6358.7 & 11347.9 \\
\hline \multicolumn{7}{|c|}{ Pop corn (Pool-12) } \\
\hline Sept 1 & 696.2 & 4417.8 & 6193.3 & 7151.6 & 8460.7 & 8872.3 \\
\hline Oct 1 & 743.2 & 4738.7 & 5059.6 & 6127.4 & 6721 & 6365.8 \\
\hline Nov 1 & 932.8 & 3022.6 & 2751 & 4568.5 & 7901.1 & 8863.2 \\
\hline $\operatorname{LSD}(0.05)$ & 75.23 & 239.12 & 326.44 & 555.72 & 387.65 & 832.5 \\
\hline
\end{tabular}

\section{Pheno-thermal index}

The effect of combination of growing conditions and cultivars on pheno-thermal indices (PTI) from sowing to emergence, emergence to knee high (KH), KH to tasseling, tasseling to anthesis, anthesis to grain filling and grain filling to maturity was influenced significantly by their interaction (Table 4 ). All the cultivars and planting dates had shown significantly higher PTI at the early stages and gradually decreased towards the maturity stage, however, the higher pheno-thermal indices were recorded for early plating $\left(1^{\text {st }}\right.$ September $)$ than the late planting $\left(1^{\text {st }}\right.$ October and $1^{\text {st }}$ November $)$ to all the cultivars. The higher temperature and lengthy days after anthesis stages of late planting maize showed the lowest days to attain the accumulative heat unit within the shorter periods and hence recorded the lesser PTI values at advanced growth stages at maturity period during spring. The decrease in PTI at later stage was also due to the increasing number of growth duration at the advanced phenological stages of the maize. At the initial stages, the growth duration was lower and then increased with increasing plant age. The GDD was also increasing with plant age. Hence, their ratio was found to be narrower at advanced stages. Similar results in wheat cultivars were 
reported by Rajput et al. (1987). But in maize, the higher values of PTI were observed at later stages when it was planted during spring (Amgain, 2011).

Table 4. Pheno-thermal index (PTI) at different phonological stages of different maize cultivars as affected by planting time

\begin{tabular}{|c|c|c|c|c|c|c|}
\hline \multirow[b]{2}{*}{ Treatment } & \multicolumn{6}{|c|}{ Growth stages of maize } \\
\hline & $\begin{array}{l}\text { Sowing- } \\
\text { Emergence }\end{array}$ & $\begin{array}{l}\text { Emergence- } \\
\text { Knee height }\end{array}$ & $\begin{array}{c}\text { Knee } \\
\text { high- } \\
\text { Tasseling }\end{array}$ & $\begin{array}{l}\text { Tasseling- } \\
\text { Anthesis }\end{array}$ & $\begin{array}{l}\text { Anthesis- } \\
\text { Grain fill }\end{array}$ & $\begin{array}{c}\text { Grain } \\
\text { filling- } \\
\text { Maturity }\end{array}$ \\
\hline \multicolumn{7}{|c|}{ Rampur Composite } \\
\hline Sept 1 & 22.97 & 19.68 & 18.76 & 17.57 & 14.67 & 12.73 \\
\hline Oct 1 & 21.10 & 14.76 & 13.23 & 12.17 & 10.38 & 9.45 \\
\hline Nov 1 & 12.77 & 8.56 & 7.85 & 7.71 & 8.08 & 9.30 \\
\hline \multicolumn{7}{|c|}{ QPM (Posilo Makai-1) } \\
\hline Sept 1 & 22.97 & 19.59 & 18.51 & 15.80 & 11.57 & 12.38 \\
\hline Oct 1 & 20.29 & 14.64 & 12.94 & 11.82 & 9.99 & 9.05 \\
\hline Nov 1 & 12.55 & 8.52 & 7.82 & 7.71 & 8.21 & 9.40 \\
\hline \multicolumn{7}{|c|}{ Hybrid (Gaurav) } \\
\hline Sept 1 & 22.97 & 19.47 & 18.24 & 17.14 & 14.31 & 12.28 \\
\hline Oct 1 & 20.29 & 14.59 & 12.69 & 11.72 & 9.91 & 9.49 \\
\hline Nov 1 & 12.86 & 8.49 & 7.81 & 7.71 & 8.25 & 9.51 \\
\hline \multicolumn{7}{|c|}{ Pop corn (Pool-20) } \\
\hline Sept 1 & 24.55 & 19.77 & 18.93 & 17.79 & 15.25 & 13.19 \\
\hline Oct 1 & 22.02 & 14.87 & 13.55 & 12.38 & 10.58 & 9.57 \\
\hline Nov 1 & 12.94 & 9.09 & 8.01 & 7.69 & 8.0 & 8.70 \\
\hline $\operatorname{LSD}(0.05)$ & 4.61 & 3.22 & 1.47 & 1.81 & 1.11 & 2.34 \\
\hline
\end{tabular}

\section{Heat use efficiency and grain yields of maize}

From the result (Table 5) it was observed that all the cultivars were more efficient to show more heat use efficiency at normal growing condition than the late growing condition. Under $1^{\text {st }}$ Sept planting condition, Gaurav had markedly higher HUE (3.46) followed by Posilo makai (3.30), Rampur Composite (3.03) and the lowest with Pool-12 (2.13). For both the late planting conditions all maize cultivars reduced their HUE at various magnitude in comparison to normal planting condition by following the same trend as that of normal planting. The reductions in HUE for maize cultivars planted late were higher for September vs November planting than the October vs November planting with the least with September vs October planting. The decrease in HUE due to late sowing depended on varieties and found to be higher in Gaurav Hybrid (24.86\%) in between September vs November planting followed by Posilo Makai (20.68\%) between October vs November planting and Pool-12 
$(10.38 \%)$ between September vs October planting. Rampur Composite had less reduction in HUE amongst the planting time and therefore it can be concluded that it is the best cultivar for both early and late winter planting. The specialty corn cultivars QPM (Posilo makai), hybrid (Gaurav) and Pop-corn (Pool-12) have not shown the stability on HUE. The results are in accordance in spring and winter maize as noted by Amgain (2011) and in wheat as evidence with Paul and Sarker (2000), cluster bean as with Rao et al., 2000) and in pearl millet as by Singh et al., 1998).

Table 5. Heat use efficiency (HUE) of different maize cultivars as affected by planting dates

\begin{tabular}{lcccccc}
\hline \multirow{2}{*}{ Cultivar } & \multicolumn{3}{c}{ Heat use efficiency (HUE) } & \multicolumn{3}{c}{ Reduction (\% ) due to late sowing } \\
\cline { 2 - 7 } & Sept 1 & Oct 1 & Nov 1 & Sept vs Oct & Sept vs Nov & Oct vs Nov \\
\hline Rampur Comp. & 3.03 & 2.94 & 2.44 & 3.29 & 19.73 & 17.0 \\
Posilo Makai-1 & 3.30 & 3.19 & 2.53 & 3.33 & 22.33 & 20.68 \\
Gaurav & 3.46 & 3.13 & 2.60 & 9.83 & 24.86 & 16.67 \\
Pool-12 & 2.13 & 1.90 & 1.66 & 10.38 & 21.70 & 12.63 \\
\hline
\end{tabular}

The date of planting is major governing factors in crop production and it is considered to be low-cost high monetary returned under best management conditions. The September planting maize has been producing higher yield than the subsequent late plantings. The percentage reduction in yield was less for September vs October planting than the October vs November planting and the highest for Sept vs November planting (Table 6). This might be due to the low temperature from sowing to the long vegetative growth stages of maize due to late planting resulting less dry matter and less photosynthate formation. Rao and Singh (2007) had also found the lesser yield of pearl millet when planted delayed in Rajsthan, India.

Table 6. Grain yield (t/ha) and yield reduction due to delayed planting in different maize cultivars

\begin{tabular}{lcccccc}
\hline \multirow{2}{*}{ Maize cultivars } & \multicolumn{3}{c}{ Grain yield (t/ha) } & \multicolumn{3}{c}{ Yield reduction (\% ) due to late sowing } \\
\cline { 2 - 7 } & Sept 1 & Oct 1 & Nov 1 & Sept vs Oct & Oct vs Nov & Sept vs Nov \\
\hline Rampur Comp. & 5.1 & 4.0 & 3.43 & 21.52 & 14.25 & 32.75 \\
Posilo Makai-1 & 5.50 & 4.27 & 3.64 & 22.36 & 14.75 & 33.82 \\
Gaurav & 5.86 & 4.45 & 3.83 & 24.06 & 13.93 & 34.46 \\
Pool-12 & 3.45 & 2.42 & 2.02 & 29.86 & 16.53 & 41.45 \\
\hline
\end{tabular}




\section{Conclusions}

Rampur Composite is better to show greater stability to solar energy (heat), growing degree days (GDD) and heat use efficiency than the other cultivars during winter that's why its popularity amongst the farmer of terai and inner terai is higher. The specialty corn cultivars QPM, Hybrid and Pop-corn were not stable to heat and fitted only for timely sowing and suggested to grow for normal planting during winter. However, more research is needed in large areas to validate this result further over years and locations.

\section{Acknowledgements}

The datasets presented in this study was taken from the project report accomplished with the financial supports of Nepal Academy of Science and Technology (NAST). The author has been very much thanked to NMRP, Rampur for providing the daily weather records and $\mathrm{Mr}$ Santosh Tripathi, Scientist $\left(\mathrm{S}_{1}\right)$, NGLRP for constantly conveying the weather data during the periods of experimentation.

\section{References}

Amgain, LP. 2011. Accumulated heat unit and phenology of different maize cultivars as influenced by planting time and seasons. Papers submitted to IAAS J vol 31.

Bierhuizen, JF. 1973. The effect of temperature on plant growth, development and yield. (In) Plant Response to Climate Factors. Proc. Uppsala Symposium (Paris): 89-98.

Bishnoi, OP, S Singh and R Niwas. 1995. Effect of temperature on phonological development of wheat (Triticum aestivum L.) crop in different row orientations. Indian J.Agric. Sci. 65:211214.

Bonhomme, R, M Dereeux and GO Edmeades. 1994. Flowering of diverse maize cultivars $\mathrm{n}$ relation to temperature and photoperiod in multi-location field trials. Crop Science 34: 156-164.

Doraiswamy, PC and DR Thompson. 1982. A crop moisture stress index for large areas and its application in the production of spring wheat phenology. Agril Meterol 27: 290-294.

Ghosh, DC, P Nandi and B De. 2000. Phenological development and productivity of wheat (Triticum aestivum L.) at different dates of sowing. Indian J. Agric. Sci. 70(6): 390-395.

Gurung, DB. 2010. National Co-ordinators' Report on Maize: Paper presented in the $26^{\text {th }}$ Summer Crop Workshop at Rampur Chitwan, Nepal (3-5 March, 2010).

Jones, JW, G Hoogenboom, CH Porter, KJ Bootee, WD Batchelor, LA Hunt, PW Wilkens, U Singh, AJ Gijsman and JT Ritchie. 2003. The DSSAT Cropping System Model. European Journal of Agronomy 18:235-265.

NMRP (National Maize Research Program). 2008. Annual Report, National Maize Research Program, Rampur Chitwan, Nepal

Pual, NK and DK Sarker. 2000. Accumulated heat units and phenology relationships in wheat as influenced by sowing dates. Bangladesh J. Bot. 29(1): 49-54. 
Rajput, RP. 1980. Response of soybean crop to climate and soil environments. Ph D thesis. Indian Agricultural Research Institute, Pusa, New Delhi.

Rajput, RP, MR Deshmukh and VK Paradkar. 1987. Accumulated heat unit and phenology relationships in wheat (Triticum aestivum L.) as influenced by planting dates under late sown conditions. J Agron. Crop Sci. 159: 345-348.

Rao, AS and RS Singh. 2007. Evapo-transpiration rates and water-use efficiency of HHB 67 pearl millet (Pennisetum glaucum) under arid climatic conditions. Indian J. Agric. Sci. 77 (12): 810-13.

Rao, AS, RS Singh, NL Joshi and YS Ramakrishna. 2000. Evapo-transpiration, water and radiationutilization of cluster bean (Cyampsis tetragonoloba). Indian J. Agric. Sci. 70 (1): 149-153.

Rao, VUM, D Singh and R Singh. 1999. Heat use efficiency of winter crops in Haryana. Journal of Agro-meteorology 1 (2): 143-148.

Reddy, SR. 2009. Agronomy of Field Crops. Kalyani Publishers, Third Revised Edition. Kalyani Publishers, Ludhiana, India. pp. 9-124.

Ritchie, JT and DS Nesmith. 1991. Temperatures and crop development. Modeling plant and soil systems. Agronomy Monograph No. 31, ASA-CSSA-SSSA, Madison, WI53711, USA.

Sandhu, IS, AR Sharma and HS Sur. 1999. Yield performance and heat unit requirement of wheat (Triticum aestivum L.) varieties as affected by sowing dates under rainfed conditions. Indian J. Agric. Sci. 69: 175- 179.

Sikder, S. 2009. Accumulated heat unit and phenology of wheat cultivars as influenced by late sowing heat stress condition. J Agric Rural Dev 7 (1 \&2): 57-64.

Singh, RSN, L Joshi and HP Singh. 1998. Pearl millet phenology and growth in relation to thermal time under arid environment. Journal of Agronomy and Crop Science 180 (2): 83-91.

Sreenivas, G, M Devender Reddy and D Raji, Reddy. 2010. Agro-meteorological indices in relation to phenology of aerobic rice. Journal of Agro-meteorology 12 (2): 241-244. 